\title{
Researches on the delimitation between the water aeration and oxygenation processes
}

\author{
Rasha Cusma ${ }^{1}$, Nicolae Băran ${ }^{1}$, Nicolae Vlad Sima ${ }^{1}$, Mihaela Petroșel $^{1}$, Remus Voicu ${ }^{1}$, \\ Mariana Mirela Stoican (Prisecaru) ${ }^{1}$ and Mihaela Constantin ${ }^{1, *}$ \\ ${ }^{1}$ University Politehnica of Bucharest, Faculty of Mechanical Engineering and Mechatronics, Splaiul \\ Independenței, no. 313, Bucharest, Romania
}

\begin{abstract}
Considering that in certain papers the aeration processes are confused with the oxygenation processes, a distinction between them must be made. The paper presents modern water aeration and oxygenation installations. The experimental results obtained for the two categories of installations are highlighted. Theoretical and experimental researches aim to increase the concentration of dissolved oxygen in water; this can be done in two ways: I - by introducing atmospheric air into the water; II - by introducing a gaseous mixture consisting of atmospheric air and oxygen. Version II is better, the results being shown in Figure 11.
\end{abstract}

\section{Introduction}

In order to increase the dissolved oxygen content in water, there are several methods and procedures that do not differentiate between the notion of "water aeration" and " water oxygenation"; there are papers in which the two expressions are confused [1]. [3]:

Water aeration is achieved by introducing atmospheric air into the water as follows [2]

1. By mechanical aeration;

2. By pneumatic aeration.

- In the case of mechanical aeration, the air is introduced into the water under the action of rotors, blades, etc. performing surface aeration.

- In the case of pneumatic aeration, the air is sent to diffusers made of plastics, ceramics, etc.; these diffusers are placed below the water level, thus aerating the water with air bubbles.

The aeration equipment's are classified according to the following criteria [4] [5]:

* By the way of obtaining the interfacial contact surface:

- equipment's that sprays water in the air and equipment in cascade;

- equipment's that disperses the gas in the water (deep mechanical aerators, etc.);

- mixed equipment's - spray the water in the form of drops and entrain the air through the jet effect upon mass re-entry of the water from the basin (surface mechanical aerators).

* By the movement of the active body of the aeration equipment:

${ }^{*}$ Corresponding author: i.mihaelaconstantin@gmail.com 
- static equipment's (static aerators, ejectors, etc.);

- dynamic equipment's (surface or depth mechanical aerators).

* Depending on the type of gas used for aeration:

- equipment's that disperses air into water (deep mechanical aerators, pneumatic aerators, ejectors, etc.);

- equipment's that disperses pure oxygen in water (pneumatic type);

- equipment's with ozone or ozone enriched air in water (such as fluid jet pumps).

* By the constructive solution:

- pneumatic equipment's with porous diffusers, static aerators, etc.;

- surface mechanical equipment's, medium or high depth with rotor, brush, etc. ;

- mixed equipment's.

* By the immersion mode of the dispersion device:

- surface equipment's (mechanical surface aerators with rotor or brush);

- medium depth equipment's - the dispersion device is located at a depth of $1 \div 2 \mathrm{~m}$ (INKA type pneumatic devices, medium depth mechanical aerators, etc.);

- deep water equipment's - the dispersion device is located at about $3 \div 120 \mathrm{~m}$ (pneumatic, injector, mechanical deep water equipment's, etc.).

\section{Boundary between water aeration and water oxygenation installations}

This delimitation refers to the nature and composition of the gas introduced into the water.

In table 1 a clear distinction is made between the two processes (two installations), namely [1], [2], [3]:

I - Aeration installations;

II - Oxygenation installations.

Table 1. Classification of pneumatic aeration installations.

\begin{tabular}{|c|c|c|c|c|c|}
\hline $\begin{array}{c}\text { Installation } \\
\text { type }\end{array}$ & $\begin{array}{c}\text { Nature of } \\
\text { the gas }\end{array}$ & Gas source & $\begin{array}{l}\text { Volumetric gas } \\
\text { composition }\end{array}$ & Advantages & Disadvantages \\
\hline $\begin{array}{c}\text { I. } \\
\text { Installation } \\
\text { for water } \\
\text { aeration }\end{array}$ & Air & $\begin{array}{c}\text { Air } \\
\text { compressor }\end{array}$ & $\begin{array}{c}21 \% \mathrm{O}_{2}+79 \% \\
\mathrm{~N}_{2}\end{array}$ & $\begin{array}{l}\text { Source available } \\
\text { for free }\end{array}$ & $\begin{array}{l}\text { Electricity } \\
\text { consumption }\end{array}$ \\
\hline \multirow{3}{*}{$\begin{array}{l}\text { II. } \\
\text { Installations } \\
\text { for water } \\
\text { oxygenation }\end{array}$} & \multirow{3}{*}{$\begin{array}{c}\text { Air }+ \\
\text { oxygen }\end{array}$} & $\begin{array}{c}\text { Air } \\
\text { compressor }+ \\
\mathrm{O}_{2} \text { from a } \\
\text { cylinder } \\
\end{array}$ & $\begin{array}{c}\mathrm{Air}+(20 \% \div \\
80 \%) \mathrm{O}_{2}\end{array}$ & $\begin{array}{c}\text { Reduction of } \\
\text { water } \\
\text { oxygenation time }\end{array}$ & $\begin{array}{c}\text { Cost } \mathrm{O}_{2} \text { from a } \\
\text { cylinder }\end{array}$ \\
\hline & & $\begin{array}{c}\text { Oxygen } \\
\text { concentrators }\end{array}$ & $95 \% \mathrm{O}_{2}+5 \% \mathrm{~N}_{2}$ & $\begin{array}{c}\text { Reduction of } \\
\text { water } \\
\text { oxygenation time }\end{array}$ & $\begin{array}{l}\text { Electricity } \\
\text { consumption }\end{array}$ \\
\hline & & $\begin{array}{l}\text { Ozone from } \\
\mathrm{O}_{3} \text { generators }\end{array}$ & Air $+\mathrm{O}_{3}$ & $\begin{array}{c}\text { Reduction of } \\
\text { water } \\
\text { oxygenation time }\end{array}$ & $\begin{array}{l}\text { Electricity } \\
\text { consumption }\end{array}$ \\
\hline
\end{tabular}

It is useful to sort the expressions, as follows:

I. Water aeration refers only to the introduction of atmospheric air into water $\left(21 \% \mathrm{O}_{2}+\right.$ $79 \% \mathrm{~N}_{2}$ );

II. Water oxygenation refers to the introduction of gaseous mixtures in which the oxygen exceeds $21 \%$.

Obviously I + II have the same purpose, namely to increase the dissolved oxygen concentration in water. When increasing the percentage of $\mathrm{O}_{2}$ introduced into water by more than $21 \%$, the time in which water oxygenation takes place $\left(\mathrm{C}_{0} \rightarrow \mathrm{C}_{\mathrm{s}}\right)$ is reduced. 


\section{The installation of water aeration}

Fine air bubbles generators (FBG) will be used to introduce air into water. From the literature it is known that the rate of oxygen transfer to water increases with decreasing air bubble diameter; the air bubble diameter of is a function of the orifice diameter in the perforated plate of the FBG.

The gas bubbles (atmospheric air or a mixture of gases) can be classified according to the data in figure 1.

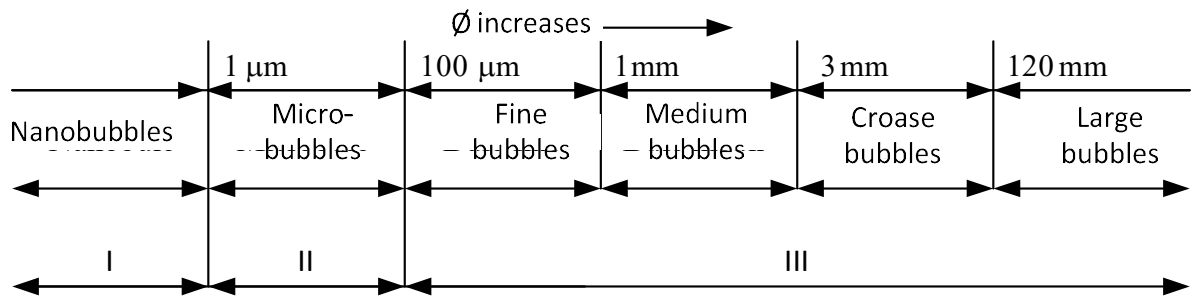

Fig. 1. Classification of gas bubbles according to their diameter I - the area where the gas bubbles can be observed under the microscope;

II - the area where gas bubbles can be observed with difficulty;

III - the area where gas bubbles can be observed with the naked eye.

Figure 2 shows a FBG that has a rectangular shape orifices plate. Taking into account the dimensions of the water tank and the height of the water layer, a section of air outlet in water of $1.2 \cdot 10^{-6} \mathrm{~m}^{2}[6]$ [7] has been chosen, resulting in a number of orifices of $\varnothing 0.1 \mathrm{~mm}$ equal to:

$$
n=\frac{A}{\frac{\pi \cdot d_{0}^{2}}{4}}=\frac{1.2 \cdot 10^{-6}}{\frac{\pi \cdot\left(0.1 \cdot 10^{-3}\right)^{2}}{4}}=152 \text { orifices }
$$

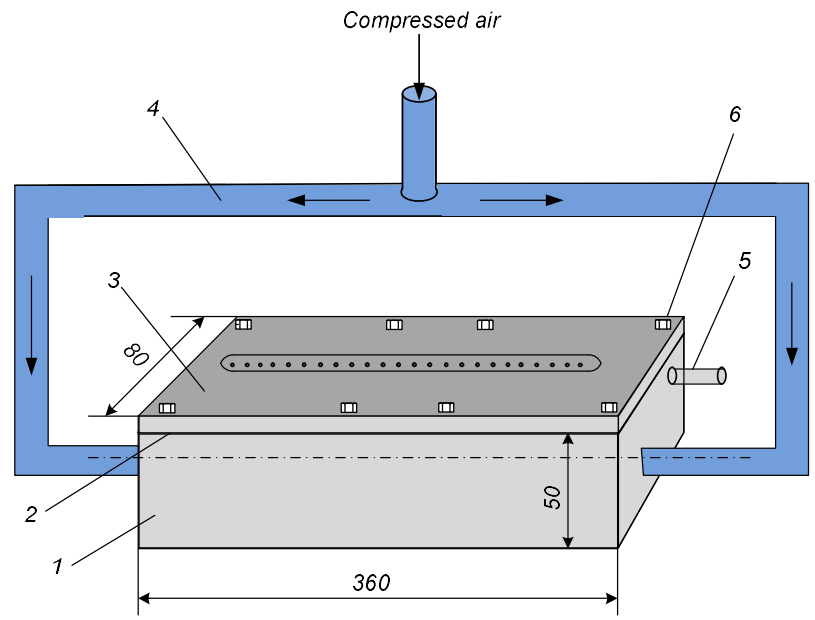

Fig. 2. FBG with rectangular orifices plate [4]

1- compressed air tank; 2 - sealing system; 3 - orifices plate; 4 - compressed air line; 5 - connection to the manometer; 6 - elements for fastening the orifices plate 
The plate (3) contains 152 orifices (Ø $0.1 \mathrm{~mm}$ ) made using a KERN Micro machine; the constructive solution of this FBG is an original and very efficient constructive solution.

The framing of this FBG in the experimental installation is shown in figure 3.

During the measurements, the following data were kept constant:

- Air flow rate: $\dot{V}=0.6 \mathrm{~m}^{3} / \mathrm{h}$;

- Air pressure at the entrance of the FBG: $\mathrm{p}=573 \mathrm{mmH}_{2} \mathrm{O}$;

- Hydrostatic load: $\mathrm{H}=500 \mathrm{mmH}_{2} \mathrm{O}$;

- Water temperature $24{ }^{\circ} \mathrm{C}$ for which from [3]: $\mathrm{C}_{\mathrm{s}}=8.4 \mathrm{mg} / \mathrm{dm}^{3}, \mathrm{C}_{\mathrm{o}}=5.84 \mathrm{mg} / \mathrm{dm}^{3}$.

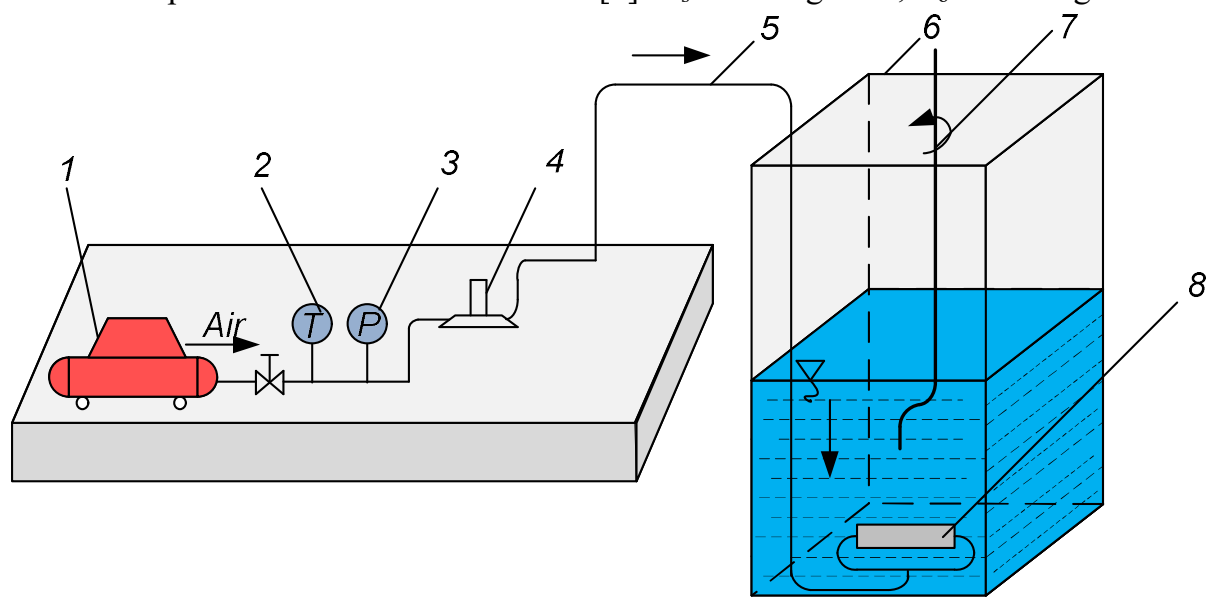

Fig. 3. Installation scheme for the introduction of atmospheric air into water [4]:

1-electrocompressor; 2- digital thermometer; 3- digital manometer; 4- rotameter; 5- air transport pipeline; 6 - oxygen sensor; 7 - water tank; 8 - fine bubble generator.

Figure 4 shows the functioning of the studied FBG.

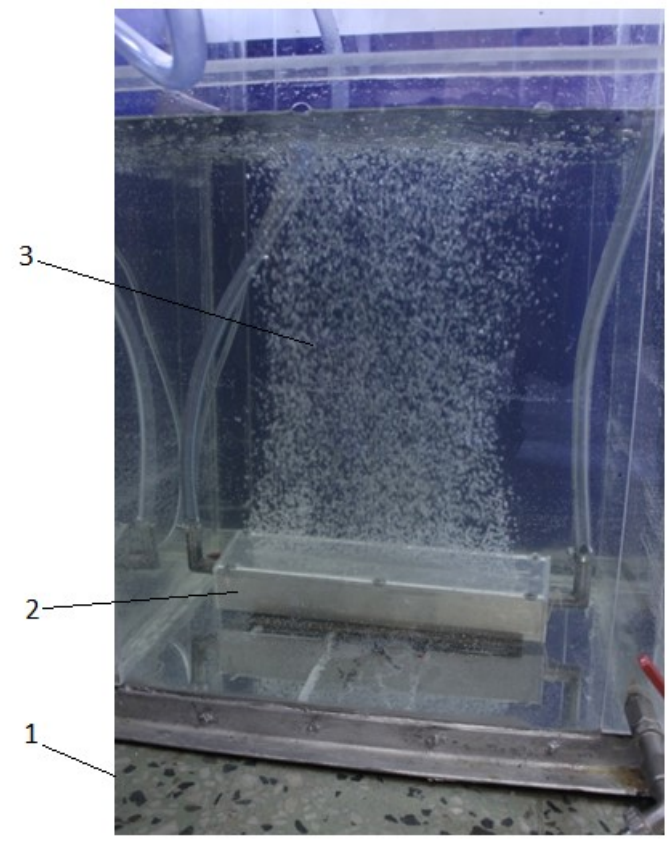

Fig. 4. FBG in operation.

1 - water tank; 2 - FBG; 3 - plane jet with air bubbles. 
Figure 4 show that the air coming out through the orifices in the straight line creates a bubble curtain, similar to a plane jet of air. The increase of the dissolved oxygen concentration in the water depends on the rate of its increase, given by the relation [8] [9] [10]:

$$
\frac{\mathrm{d} C}{\mathrm{~d} \tau}=a k_{L}\left(C_{s}-C\right)
$$

Where:

$\mathrm{ak}_{\mathrm{L}}$ - the volumetric mass transfer coefficient $\left[\mathrm{s}^{-1}\right]$;

$\mathrm{C}_{\mathrm{s}}$ - the mass concentration of oxygen at saturation in liquid phase $\left[\mathrm{kg} / \mathrm{m}^{3}\right]$;

$\mathrm{C}$ - the current mass concentration of oxygen in the liquid phase $\left[\mathrm{kg} / \mathrm{m}^{3}\right]$.

The relation (2) was numerically integrated and a calculation program was performed, the results being presented in figure 5, curve 1 .

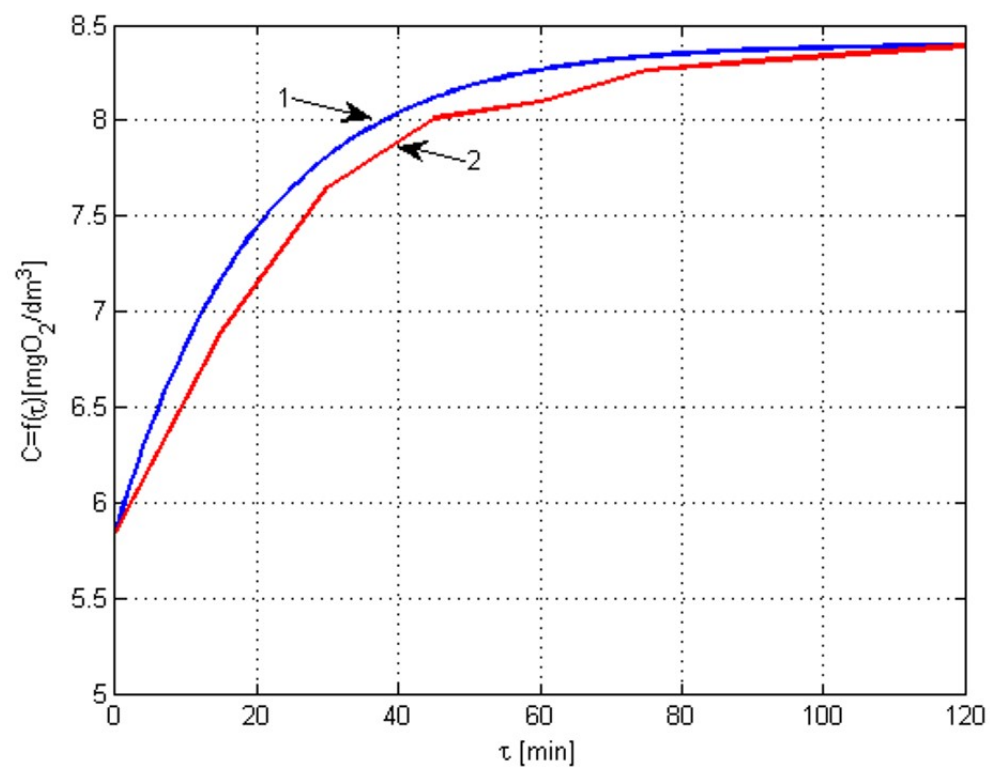

Fig. 5. $\mathrm{C}_{\mathrm{O} 2}=\mathrm{f}(\tau)$ for atmospheric air

1 - curve drawn on the basis of theoretical data;

2 - curve drawn on the basis of experimental data.

In the experimental researches, the dissolved oxygen concentration in the water was measured from 15 in 15 minutes resulting curve 2 (figure 5). Between the two curves (1) and (2) in figure 5 a good coincidence is observed.

\section{Water oxygenation installations}

The operating scheme and the experimental results for three water oxygenation installations are presented.

4.1. Installation that uses a mixture of atmospheric air and oxygen from a cylinder.

4.2. Installation that uses low nitrogen air.

4.3. Installation that uses a mixture of air and ozone.

All the three installations 4.1, 4.2, 4.3 were built in the laboratory of the Department of Thermotechnics, Engines, Thermal and Refrigeration Equipment's. 


\subsection{Installation that uses a mixture of atmospheric air and oxygen from a cylinder}

The working parameters of the installation are:

- air flow: $\dot{V}=600 \mathrm{dm}^{3} / \mathrm{h}$;

- air pressure: $\mathrm{p}=573 \mathrm{mmH}_{2} \mathrm{O}$;

- hydrostatic load: $\mathrm{H}=500 \mathrm{mmH}_{2} \mathrm{O}$; the hydrostatic load is: $\mathrm{p}=\rho \mathrm{g} \mathrm{H}\left[\mathrm{N} / \mathrm{m}^{2}\right]$, where $\mathrm{H}$ comprises the height at which the water is to be pumped and the pressure losses on the hydraulic circuit.

- working time: two hours.

For atmospheric air there is rotameter (4) in figure 6, and rotameter (4') for the oxygen from the cylinder.

Operating variants:

$\dot{V}_{O_{2}}=150 \mathrm{dm}^{3} /$ h, i.e. $25 \%$ of $\dot{V}$;

$\dot{V}_{O_{2}}=300 \mathrm{dm}^{3} /$ h, i.e. $50 \%$ of $\dot{V}$;

$\dot{V}_{O_{2}}=450 \mathrm{dm}^{3} /$ h, i.e. $75 \%$ of $\dot{V}$;

$\dot{V}_{O_{2}}=600 \mathrm{dm}^{3} /$ h, i.e. $100 \%$ of $\dot{V}$.

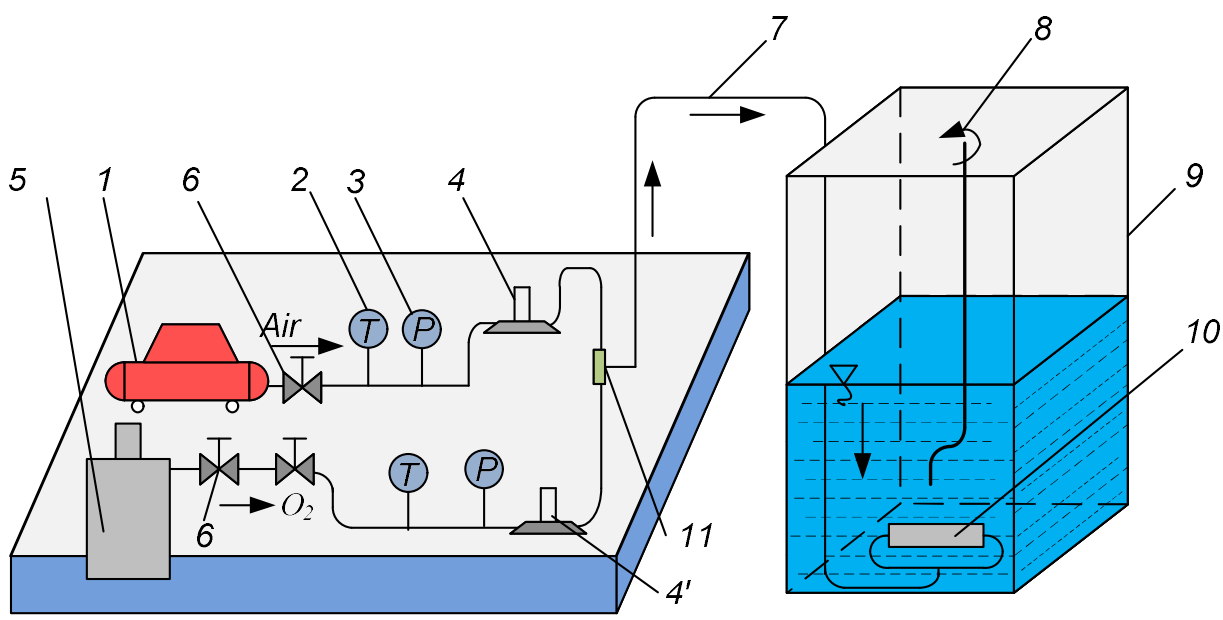

Fig. 6. Scheme of the installation for introducing a gas mixture: air + oxygen from the cylinder.

1- electrocompressor; 2 - thermometer; 3 - manometer; 4,4'- rotameter;

5- oxygen cylinder; 6 - pressure reducer; 7- air duct + oxygen;

8- probe for measuring the concentration of oxygen, dissolved in water; 9- water tank;

10- fine bubble generator (FBG); 11- T-joint.

Figure 7 shows an overview of the experimental installation. 


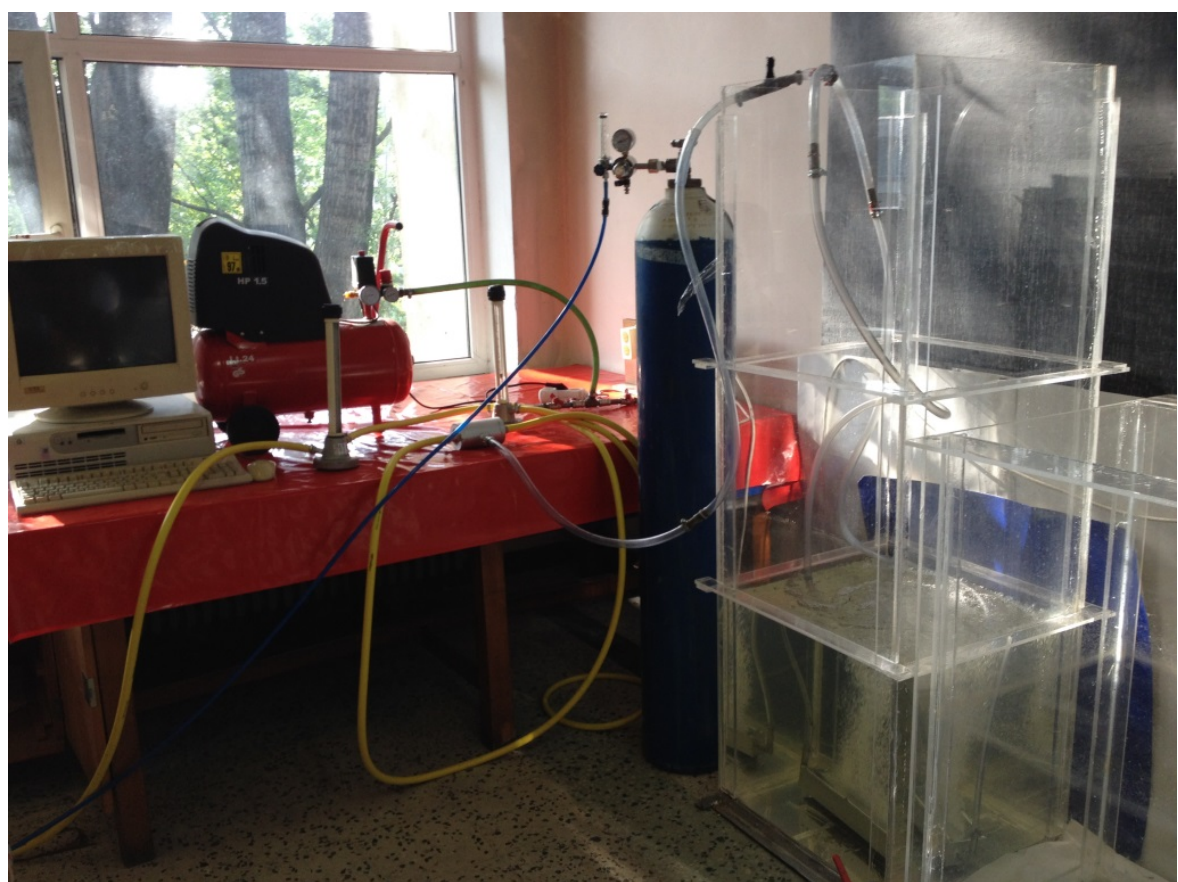

Fig. 7. Overview of the experimental installation for the introduction of a mixture (air + oxygen).

In the centre of the photo one can see the oxygen cylinder, and on the right side there is the transparent plexiglass water tank.

\subsection{Installation that uses low nitrogen air}

Figure 8 shows two oxygen concentrators each delivering $300 \mathrm{dm}^{3} / \mathrm{h}$ of gas with the volumetric composition $\mathrm{O}_{2}=95 \%, \mathrm{~N}_{2}=5 \%$.
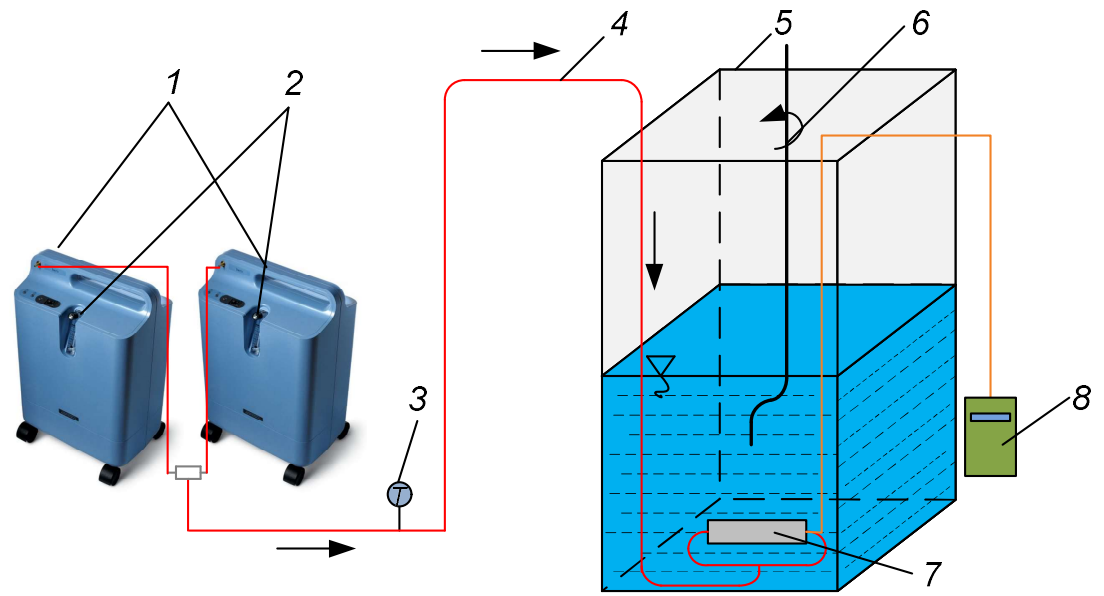

Fig. 8. FBG supplied with air with low nitrogen content

1- oxygen concentrators; 2 - rotameter; 3 - thermometer; 4- gas pipe $\left(95 \% \mathrm{O}_{2}+5 \% \mathrm{~N}_{2}\right)$; 5- water tank; 6- oxygen sensor; 7- FBG; 8- manometer.

In figure 9, on the left side, two oxygen concentrators (1) are observed, each device being equipped with a rotameter. 


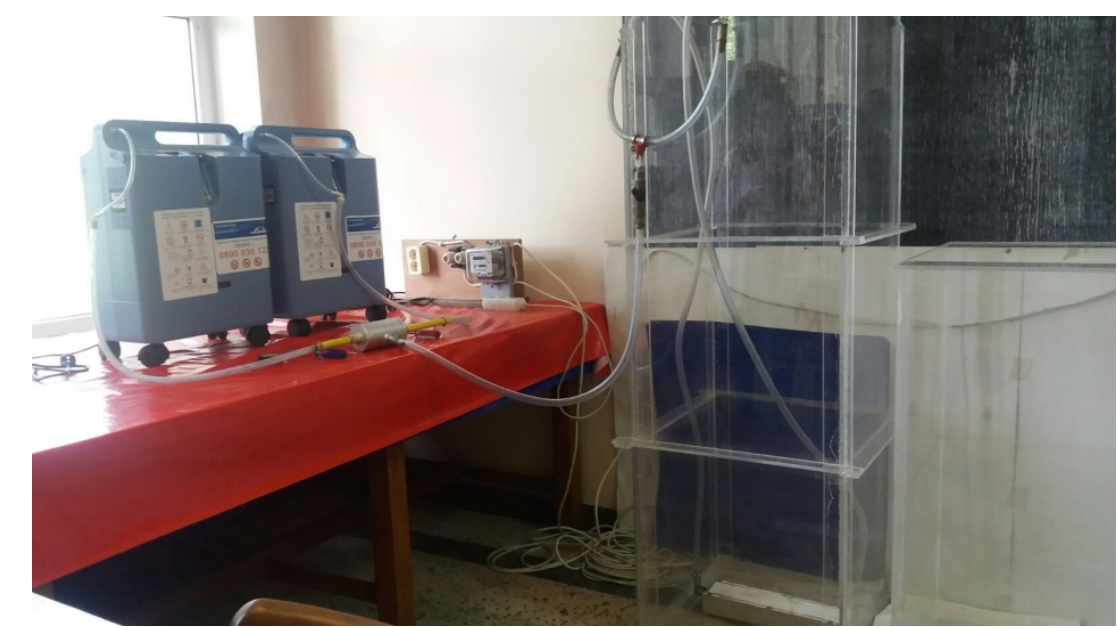

Fig. 9. Overview of the experimental installation for low nitrogen content air supply [5].

The atmospheric air extracted from the atmosphere is compressed and sent to the zeolite filters where nitrogen is retained; upon exiting the unit, a gas containing $95 \%$ oxygen is obtained.

\subsection{Installation that uses a mixture of air and ozone}

Figure 10 shows the ozone generator (4); at the exit from it the produced ozone is mixed with air and enters the rotameter (7) and then into the FBG (11) [11] [12].

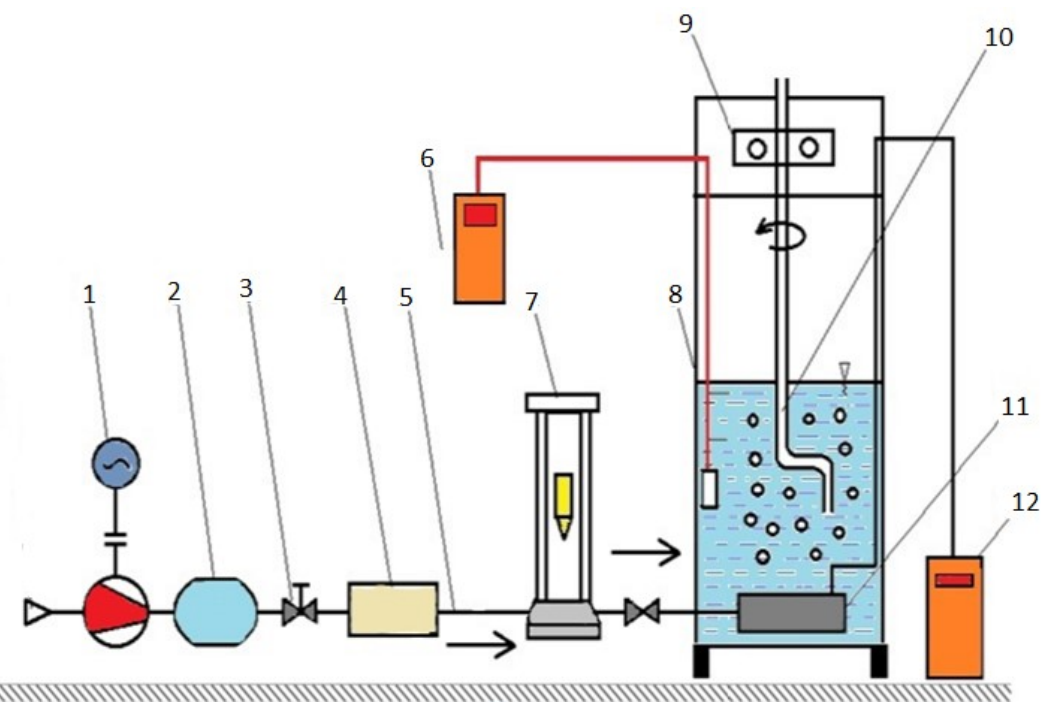

Fig. 10. Scheme of the experimental installation for water oxygenation researches, by introducing into the water tank a gas mixture containing atmospheric air and ozone

1- electrocompressor; 2- compressed air tank; 3- pressure reducer; 4- ozone generator; 5- pipe; 6- thermometer with digital indication; 7- rotameter; 8- water tank; 9- mechanism for the rotation of the oxygen probe in water; 10 - oxygen probe; 11 - fine bubble generator; 12 - manometer with digital indication.

The compressed air supplied by the compressor (1) passes through the ozone generator (4), through the rotameter (7) and enters the FBG (11). 
Depending on the water temperature $\left(\mathrm{t}=23.7^{\circ} \mathrm{C}\right)$ in [3] the saturation concentration values are found for:

- Atmospheric air: $\mathrm{C}_{\mathrm{s}}=8.4 \mathrm{mg} / \mathrm{dm}^{3}$;

- Air $+25 \% \mathrm{O}_{2}: \mathrm{C}_{\mathrm{s}}=10.73 \mathrm{mg} / \mathrm{dm}^{3}$;

- Air $+50 \% \mathrm{O}_{2}: \mathrm{C}_{\mathrm{s}}=21.46 \mathrm{mg} / \mathrm{dm}^{3}$;

- Air $+75 \% \mathrm{O}_{2}: \mathrm{C}_{\mathrm{s}}=32.21 \mathrm{mg} / \mathrm{dm}^{3}$;

- Air $+100 \% \mathrm{O}_{2}: \mathrm{C}_{\mathrm{s}}=43.00 \mathrm{mg} / \mathrm{dm}^{3}$.

The value of the dissolved oxygen concentration in water was initially $5.84 \mathrm{mg} / \mathrm{dm}^{3}$.

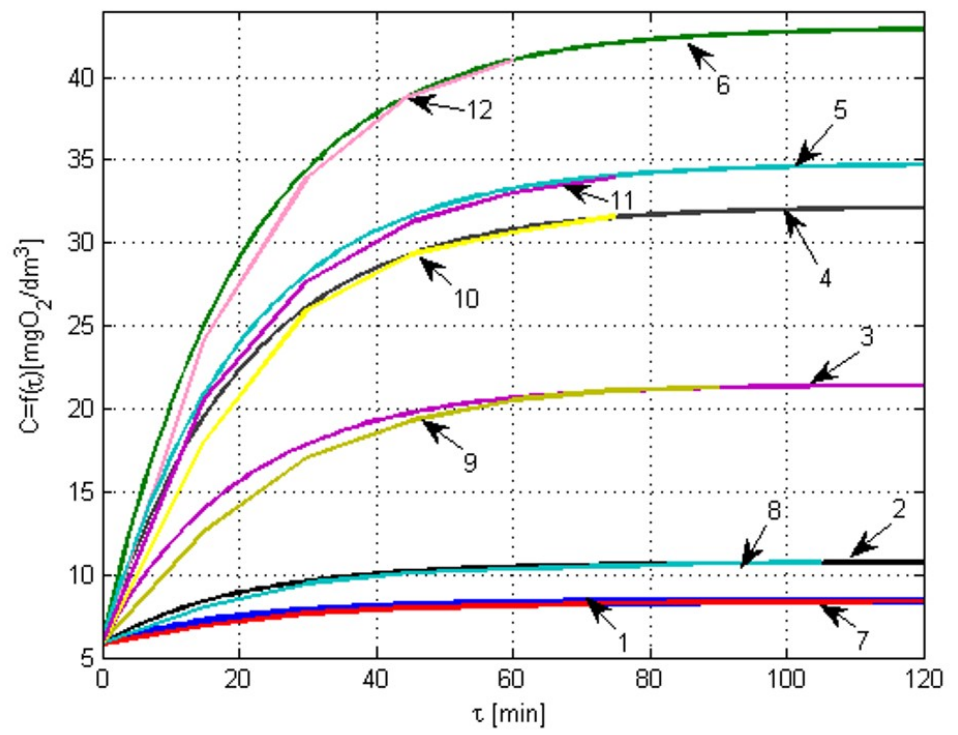

Fig. 11. Increase of dissolved oxygen concentration in water for:

1/7 - atmospheric air; $2 / 8$ - air + oxygen $\left(150 \mathrm{dm}^{3} / \mathrm{h}\right) ; 3 / 9$ - air + oxygen $\left(300 \mathrm{dm}^{3} / \mathrm{h}\right) ; 4 / 10$ - air + oxygen $\left(450 \mathrm{dm}^{3} / \mathrm{h}\right) ; 5 / 11$ - low nitrogen air; $6 / 12$ - air + oxygen $\left(600 \mathrm{dm}^{3} / \mathrm{h}\right)$.

$1,2,3,4,5,6$ - curve drawn on the basis of theoretical data;

$7,8,9,10,11,12$ - curve drawn on the basis of experimental data time.

Figure 10 shows the change of dissolved oxygen concentration in water as a function of

The curves 1, 2, 3, 4, 5 and 6 are plotted on the basis of theoretical data, and the curves 1 ', 2', 3 ', 4', 5 'and 6' are plotted on the basis of experimental data.

\section{Conclusions}

a) The fine bubbles generator with $0.1 \mathrm{~mm}$ orifices is original construction and very efficient solution in the process of water aeration and oxygenation.

b) The results obtained in a theoretical way (figure 5 and figure 11) coincide well with the experimental data.

c) The value of dissolved oxygen concentration in water, at saturation, is reached most rapidly when pure oxygen is introduced into water (curve 6).

d) Future researches will follow the use of microtechnologies and nanotechnologies in water aeration processes.

\section{References}


1. S. Stoianovici, D. Robescu, D. Stamatoiu, Calculul şi construcţia echipamentelor de oxigenare a apelor, Editura CERES, Bucureşti, 1985.

2. D. L. Robescu, S. Lanyi, A. Verestoy, D .Robescu, Modelarea şi simularea proceselor de epurare, Ed. Tehnică Bucureşti, 2004.

3. G. Oprina, I. Pincovschi, Ghe. Băran, Hidro-Gazo-Dinamica Sistemelor de aerare echipate cu generatoare de bule, Editura POLITEHNICA PRESS, Bucureşti, 2009.

4. Elena Beatrice Tănase, Influența compoziției gazului insuflat în apă asupra conținutului de oxIgen dizolvat, Teză de doctorat, Universitatea POLITEHNICA din București, 2017.

5. Al. Pătulea, Influența parametrilor funcționali și a arhitecturii generatoarelor de bule fine asupra eficienței instalațiilor de aerare, Teză de doctorat, Universitatea POLITEHNICA din București, 2012.

6. Ionela Mihaela Căluşaru, N. Băran, Al. Pătulea, The influence of the constructive solution of fine bubble generators on the concentration of oxygen dissolved in water, Advanced Materials Research, Trans Tech Publications, Switzerland, vols. 538-541, 2012, pp .2304-2310.

7. Ionela Mihaela Constantin, N. Băran, Elena Beatrice Tănase, A New Solution for Water Oxygenation, International Journal of Innovative Research in Advanced Engineering (IJIRAE), Vol. 2, Issue 7, 2015, pp. 49-52.

8. Ionela Mihaela Căluşaru-Constantin, Elena Beatrice Tănase, N. Băran an, Rasha Mlisan-Cusma, Researches Regarding the Modification of Dissolved Oxygen Concentration in Water, IJISET - International Journal of Innovative Science, Engineering \& Technology, Vol. 1 Issue 6, 2014, pp. 228-231.

9. Elena Beatrice Tănase, N. Băran, Rasha Mlisan, An Efficient Solution for Water Oxygenation, Asian Engineering Review Vol. 1, No. 3, 36-40, 2014.

10. Droste Ronald L. Theory and Practice of Water and Wastewater Treatment, 1996. ISBN 978-0-471-12444-3 - John Wiley \& Sons Inc.

11. A. G. Roza, Cercetări privind utilizarea ozonului la oxigenarea apelor, Teză de doctorat, Universitatea POLITEHNICA din București, 2019.

12. Roza Giovani Albertino, Albu Nicoleta Dorina, Donţu Octavian, Moga Corina, Băran Nicolae, Constantin Mihaela, „Researches on the use of ozone generators for wastewater treatment", Proceedings of the International Conference of Mechatronics and Cyber-Mix Mechatronics - 2019, pp 11-21. 